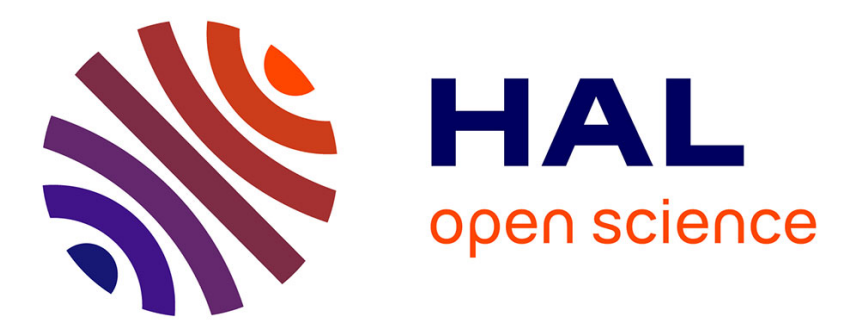

\title{
Fast filtration for metabolome sampling of suspended animal cells
}

Martin Volmer, Stefan Northoff, Sebastian Scholz, Tobias Thüte, Heino Büntemeyer, Thomas Noll

\section{- To cite this version:}

Martin Volmer, Stefan Northoff, Sebastian Scholz, Tobias Thüte, Heino Büntemeyer, et al.. Fast filtration for metabolome sampling of suspended animal cells. Biotechnology Letters, 2010, 33 (3), pp.495-502. 10.1007/s10529-010-0466-7 . hal-00640458

\section{HAL Id: hal-00640458 https://hal.science/hal-00640458}

Submitted on 12 Nov 2011

HAL is a multi-disciplinary open access archive for the deposit and dissemination of scientific research documents, whether they are published or not. The documents may come from teaching and research institutions in France or abroad, or from public or private research centers.
L'archive ouverte pluridisciplinaire HAL, est destinée au dépôt et à la diffusion de documents scientifiques de niveau recherche, publiés ou non, émanant des établissements d'enseignement et de recherche français ou étrangers, des laboratoires publics ou privés. 


\section{Section: Animal Cell Technology}

\section{Fast filtration for metabolome sampling of suspended animal cells}

Martin Volmer - Stefan Northoff - Sebastian Scholz - Tobias Thüte · Heino Büntemeyer ·

Thomas Noll

M. Volmer $\cdot$ S. Scholz $\cdot$ T. Thüte $\cdot$ H. Büntemeyer $\cdot$ T. Noll

Institute of Cell Culture Technology

Bielefeld University, Bielefeld, Germany

S. Northoff $\cdot$ H. Büntemeyer

TeutoCell AG

Bielefeld, Germany

Corresponding Author

M. Volmer

Phone: +49 5211066323

Fax: +495211066328

E-mail: martin.volmer@uni-bielefeld.de 


\begin{abstract}
A new method for sampling suspended animal cells by fast filtration is presented that allows rapid quenching of cellular metabolism and efficient separation of the cells from culture medium. Compared to sampling with a microstructure heat exchanger or centrifugation without prior quenching, the adenylate energy charge and the measured concentrations especially of metabolites with a high turnover rate or of metabolites early in metabolic pathways were substantially higher. No leakage of ATP from the cells was observed when using iso-osmotic $\mathrm{NaCl}$ solution in the washing step. The combination of fast filtration and cold methanol extraction is therefore suitable for intracellular metabolomic studies of suspended animal cell cultures and superior to other methods currently applied.
\end{abstract}

Keywords Animal cells . Fast filtration . Metabolome . Microstructure heat exchanger . Quenching · Rapid sampling

\title{
Introduction
}

Recent years have seen an increase in systems biological approaches for the investigation of cellular processes. In this respect the "omics" technologies have not only been developed to investigate the processes within cells but also to use the obtained knowledge to improve cultivation processes. From the classical functional genomics/systems biology tools, metabolomics is the most recent technique. Unlike for bacteria and yeast (Bolten and Wittmann 2008; Faijes et al. 2007; Schaub et al. 2006; Villas-Bôas et al. 2005), there are no standard protocols for sampling and extraction of suspended animal cells. A number of different rapid sampling methods are currently used (Sellick et al. 2009; Wiendahl et al. 2007; Dietmair et al. 2010), but have not been compared to other methods in depth.

It is most important for metabolome sampling to stop the organism's metabolic activity quantitatively and rapidly. This is to avoid loss of metabolites caused by residual enzyme activity (de Koning and van Dam 1992) or quenching conditions. A standard quenching method for bacteria and yeast is cold methanol, though other protocols using a microstructure heat exchanger 
or fast filtration are also applied (Wellerdiek et al. 2009; Bolten and Wittmann 2008). Dietmair et al. (2010) showed that using methanol, as proposed by Sellick et al. (2009), causes increased cell permeabilization and leakage of intracellular components. Thus, alternative methods for the quenching of suspended animal cells are required.

Furthermore, it is of utmost importance to separate the cells from the supernatant before metabolite extraction, as residual extracellular components will interfere with the measurement of low concentrated intracellular metabolites, making filtration or pelleting by centrifugation the most suitable techniques. Both methods require a washing step to remove residual medium from the cells. Phosphate buffered saline (PBS) is widely used as washing solution (Teng et al. 2009), but the high phosphate concentration in the sample after the washing step is problematic. Phosphate is a target for metabolome analysis and in large quantities interferes with analytical methods for metabolite quantification, e.g. GC-MS. Dietmair et al. (2010) use an iso-osmotic saline solution, which is also applied in this work.

Another important step of the sample preparation process is the extraction of metabolites from cells. A number of different extraction methods are currently employed for bacteria and yeast as well as for animal cells using boiling methanol, chloroform/methanol and acidic extractions with acidic acetonitrile/methanol or acetic acid. For suspended animal cells methanol is most commonly used as extraction agent (Ritter et al. 2008; Bennett et al. 2008; Sellick et al. 2009; Dietmair et al. 2010).

Fast filtration as a sampling method for suspended animal cells has already been described by Dietmair et al. (2010) but, due to problems with the metabolite recovery they did not consider it a suitable technique. In this study we describe new method for sampling suspended animal cells using fast filtration and subsequent extraction of metabolites. Furthermore, this method was used for taking metabolite samples during a cultivation of $\mathrm{CHO}$ cells. Samples were compared to those taken by a microstructure heat exchanger method derived from Wiendahl et al. (2007) as well as to sampling without quenching.

\section{Material and methods}


Cultivation of cells

CHO DP12 cells (ATCC, CRL-12445) were cultivated using the chemically defined medium TC42 (TeutoCell AG, Germany).

Sampling using fast filtration

The fast filtration set-up contained a custom build two part PTFE filtration device. The lower part accommodated a $50 \mathrm{~mm}$ stainless steel filter support frit (Sartorius Stedim Biotechnology, Germany) and a connection for the vacuum pump and controller (CVC3000, Vacuubrand, Germany). The upper part contained a $15 \mathrm{~cm}$ polystyrene pipe of $8 \mathrm{~mm}$ diam. for application of the sample and washing solution.

For sampling with the fast filtration device a volume of cell suspension correlating to $5 \times 10^{7}$ cells total was drawn from the bioreactor using a luer-lock coupled syringe. The cell suspension was applied to the custom build PTFE filtration device and drawn through a $47 \mathrm{~mm}$ depth filter disk of $3 \mu \mathrm{m}$ nominal pore size (Type A/D, Pall Corporation, USA) using a vacuum of 40 mbar. Subsequently, $30 \mathrm{ml}$ of a $0{ }^{\circ} \mathrm{C}$ cold iso-osmotic $\mathrm{NaCl}$ solution $\left(290 \mathrm{mOsm} \mathrm{kg}{ }^{-1}\right)$ was drawn through the filter to remove residual culture medium. The filter was taken from the filtration device and placed inside a $50 \mathrm{ml}$ tube pre-cooled to $0{ }^{\circ} \mathrm{C}$. Tube and filter were frozen in liquid $\mathrm{N}_{2}$, immediately.

Sampling using a microstructure heat exchanger

A microstructure heat exchanger (Forschungszentrum Karlsruhe, Germany) was connected to a cooling unit (Julabo, Germany) maintained at $-4{ }^{\circ} \mathrm{C}$. Cell suspension from the bioreactor was drawn through the heat-exchanger with a vacuum of 180 mbar. The cooled cell suspension was collected in a glass bottle on ice and a volume correlating to $5 \times 10^{7}$ cells was transferred to pre- 
cooled $50 \mathrm{ml}$ tubes. The tubes were centrifuged for $1 \mathrm{~min}$ at $-2{ }^{\circ} \mathrm{C}$ and $3000 \mathrm{~g}$ in a fixed-angle centrifuge. The supernatant was discarded and the cell pellets were washed with $30 \mathrm{ml}$ ice-cold $\mathrm{NaCl}$ solution. The washed cell pellets were frozen in liquid $\mathrm{N}_{2}$ and stored at $-80{ }^{\circ} \mathrm{C}$ until extraction of metabolites.

Reference sampling

The cell suspension was directly drawn into $50 \mathrm{ml}$ tubes. Further treatment was according to the microstructure heat exchanger sampling protocol.

Extraction of metabolites

Pelleted cells and cells on filters were extracted using a similar protocol: $4 \mathrm{ml} 85 \%(\mathrm{v} / \mathrm{v})$ aqueous methanol at $-20{ }^{\circ} \mathrm{C}$ was added to the washed filter and cell pellets. As the filter still contains a certain volume of washing solution, $1 \mathrm{ml}$ ice-cold water was added to the pellets. Internal standards for metabolite analysis were added and incubated for $24 \mathrm{~h}$ at $-20{ }^{\circ} \mathrm{C}$. The filter was removed from the extraction solution by drawing the solution through the porous frit of an empty PD10 column (GE-Healthcare, Sweden). Subsequently, $400 \mu$ l chloroform $\left(20^{\circ} \mathrm{C}\right)$ were added and the mixture was vortexed thoroughly for $20 \mathrm{~s}$ and spun down for $10 \mathrm{~min}$ at $2000 \mathrm{rcf}$ and $20{ }^{\circ} \mathrm{C}$. The supernatant was transferred to a new $15 \mathrm{ml}$ tube and evaporated at $10{ }^{\circ} \mathrm{C}$. Extracts were resuspended in $500 \mu \mathrm{l}$ water and $500 \mu \mathrm{l}$ chloroform was added. The suspension was vortexed thoroughly for $20 \mathrm{~s}$ and re-centrifuged for $15 \mathrm{~min}$ at $2000 \mathrm{~g}$ and $20{ }^{\circ} \mathrm{C}$. Three $100 \mu \mathrm{l}$ aliquots of the aqueous phase were transfered to new $1.5 \mathrm{ml}$ tubes. The extracts were stored at $-80{ }^{\circ} \mathrm{C}$ until analysis.

Analytical methods 
A lactate dehydrogenase (LDH) test kit (Roche Diagnostics, Germany) was used to measure cell disruption given as percentage of total cellular LDH activity.

Adenosine triphosphate (ATP) was quantified using a commercial luminescence assay (Biaffin, Germany) or as described below for metabolites from the central energy metabolism.

Amino acids and pyruvate were measured using standard protocols on by HPLC (Büntemeyer 2010)

The concentrations of intracellular metabolites from the central energy metabolism were determined by HILIC-mass spectrometry (Hydrophilic Interaction Liquid Chromatography) on a MonoChrom diol column (Varian, Germany) using acetonitrile with $0.1 \%$ formic acid (A) and 5 $\mathrm{mM}$ ammonium acetate with $0.1 \%$ formic acid ( $\mathrm{pH} 3.5$, adjusted with ammonia) (B), at $0.2 \mathrm{ml}$ $\min ^{-1}$

For GC-MS analysis, the keto- and aldehyde-functions of the metabolites were converted into their oxime derivatives using methoxyamine hydrochloride. All other relevant functions like amines, carboxylic acids or hydroxyls were masked with trimethylsilyl groups resulting in volatile derivatives. Statistical errors were reduced by using ribitol as internal standard, while systematic bias were avoided by randomization. The derivatives were separated in a GC 3800 chromatograph and detected by a MS4000 mass spectrometer (both Varian, Germany). A FactorFour VF-5ms column $(30 \mathrm{~m} \times 0.25 \mu \mathrm{m} \times 0.25 \mu \mathrm{m})$ consisting of $95 \%$ methyl- and $5 \%$ phenyl-groups was used (Varian, Germany).

\section{Results and discussion}

Validation of fast filtration as means of metabolome sampling

A microstructure heat exchanger method proposed by Wiendahl et al. (2007) and the use of methanol/ammonium bicarbonate as proposed by Sellick et al. (2009) have been used for quenching animal cell suspensions to $0{ }^{\circ} \mathrm{C}$ in the sub-second scale, but residual metabolic activity still occurs below $0{ }^{\circ} \mathrm{C}$ (Sauter 2003). Therefore it is key to authentic metabolome sampling of 
animal cells to not only cool the cells down as fast as possible but also to keep overall sampling time to a minimum. Sampling using centrifugation has certain drawbacks in this respect. We found that a centrifugation time of $1 \mathrm{~min}$ at $3000 \mathrm{~g}$ is advisable for reliable results. This results in a total sampling time of about 3 min after quenching when using a washing step. Fast filtration allows sampling within $25 \mathrm{~s}$.

The shear forces caused by drawing cell suspension and washing solution through the filter are a major concern, as they can result in high rates of cell disruption during sampling. Data on LDH release during sampling with different vacuums are shown in Fig. 1.

The release of LDH from the cells is only slightly higher during filtration compared to sampling using centrifugation. Sampling at 40 mbar vacuum results in $5.43 \% \pm 0.57 \%$ LDH measured in filtrate and wash compared to $2.56 \% \pm 0.66 \% \mathrm{LDH}$ measured in supernatant and wash of reference centrifugation experiments.

An increase in vacuum results in higher amounts of LDH in the filtrate and wash due to higher shear forces caused by the increased transmembrane pressure. Lower vacuums increase the sampling time, as illustrated in Fig. 2, making 40 mbar an optimal vacuum allowing short sampling time with minimal cell damage. Higher vacuums account for increased cell disruption which leads to the loss of intracellular metabolites from the sample.

To reduce residual medium components in the extrac,t a rapid washing step is implemented in the sampling procedure. Fig. 3 shows the cellular content of four exemplary amino acids extracted from filters loaded with $10^{7}$ cells to $6 \times 10^{7}$ cells. For comparison data of reference experiments with centrifugation of $5 \times 10^{7}$ cells are shown.

Cellular amino acid concentrations were independent from the number of cells on the filter, indicating that residual extracellular components are negligible. High amounts of residual amino acids would lead to significantly higher amino acid concentrations at lower cell counts. Data of other amino acids support these findings further. The average amount of residual amino acid in the filter was calculated to be $0.19 \% \pm 0.01 \%$ of the total amino acid amount in the cell suspension used with a maximum for glycine of $0.22 \% \pm 0.04 \%$. These values are in accordance to those 
presented by Sellick et al. (2009) for direct quenching in methanol with an additional washing step.

Additionally, the slightly increased cell disruption measured when using fast filtration for sampling has no significant effect on the metabolite content. Both, sampling using fast filtration and centrifugation yielded the same results on intracellular amino acid amounts. Potential differences caused by cell disruption seem to be smaller than the error from sampling and measurement.

Fig. 4 shows the results of experiments on leakage of ATP from the cells during sampling. ATP was chosen as a model for larger polar metabolites and to compare results to data from Sellick et al. (2009), who use solutions of methanol and substances like ammonium bicarbonate for quenching and washing. No detectable leakage was observed when using an iso-osmotic solution of sodium chloride in water and only minor leakage when using pure water as washing solution. In contrast, Sellick et al. (2009) describe ATP leakage of more than $50 \%$ in a washing step. The main reason for this is the disintegration of the cell membrane due to the methanol in the quenching solution, as assessed by Dietmair et al. (2010).

Intracellular ATP was measured in this study to be about $1.5 \mathrm{fmol} \mathrm{cell}^{-1}$. While Dietmair et al. (2010) determined the intracellular ATP amount of a recombinant CHO cell line (clone C2.8 SPF) to be $4.6 \mathrm{fmol}$ cell $^{-1}$. Differences to this study might be caused by a multitude of reasons including differences in the cell line or culture conditions. A comparison with results to data for $\mathrm{CHO}$ cells from Sellick et al. (2009) is difficult as they measured intracellular concentrations instead of the cellular amount. Assuming perfectly circular cells of $12 \mu \mathrm{m}$ diam. the intracellular concentration of $6 \mathrm{mM}$ would translate into an amount of approx. $5.4 \mathrm{fmol} \mathrm{cell}^{-1}$. All these intracellular ATP amounts are well within the range Cordell et al. (2008) states as normal for CHO cells.

Pyruvate leakage from cells during fast filtration is shown in Fig. 5. Pyruvate was chosen as model for smaller polar metabolites, especially monocarboxylates, which are prone to 'bleed' during sampling. In experiments with water as washing solution' nearly all pyruvate bled from the cells. When using iso-osmotic $\mathrm{NaCl}$ solution for washing about $600 \mathrm{nmol}$ or $50 \%$ of the total pyruvate bled from the cells. The efflux of monocarboxylates, especially lactate, from cells is caused by 
concentration driven transport of proton-linked monocarboxylate transporters (MCT) rather than by diffusion across the membrane (Sharpe and Milligan 2003). Therefore, it can be assumed that the much higher release of pyruvate from the cells compared to LDH release during sampling is caused by transporters and, possibly, ion-channels rather than cell disruption. This is supported by the negligible ATP leakage as there are no ATP transporters in the cell membrane.

Application of fast filtration for metabolome sampling

To evaluate the applicability of metabolome sampling of animal cells using fast filtration samples were drawn from a bioreactor cultivation of CHO DP12 cells (Fig. 6) using different sampling protocols. Samples for metabolome analysis were taken on days three, four, and five using fast filtration and microstructure heat exchanger sampling as well as centrifugation as reference.

Fig. 7 illustrates the adenylate energy charge (AEC) measured for each sampling protocol at each sampling point. The AEC was calculated as described by Ataullakhanov and Vitvitsky (2002).

The AEC for the samples taken using the fast filtration method is higher for all sampling points. This indicates a higher efficiency of stopping the metabolic activity, as the turnover rates of ATP to ADP and AMP are rather high (Ataullakhanov and Vitvitsky 2002).

The intracellular glucose concentration for the three sampling points is shown in Fig. 8. The glucose concentration from the samples of day five of the cultivation was below the limit of detection. A higher amount of intracellular glucose is observed for the samples taken by fast filtration. This can be due to a higher quenching efficiency of the fast filtration method or to residual extracellular glucose on the filter. The latter can be ruled out by the fact, that fast filtration samples do not exhibit higher amino acid concentrations than samples taken with the other methods (data not shown).

Large differences were also found for ribose/ribulose 5-phosphate concentrations (Fig. 9). On cultivation day 5 concentrations of up to $0.243 \mathrm{fmol} \mathrm{cell}^{-1}$ were measured in fast filtration extracts 
and concentrations below $0.038 \mathrm{fmol} \mathrm{cell}^{-1}$ and $0.037 \mathrm{fmol} \mathrm{cell}^{-1}$ were measured in extracts from samples taken using the microstructure heat exchanger and centrifugation, respectively.

This strongly supports the higher quenching efficiency of the fast filtration method. By using fast filtration the metabolism of the cells was more efficiently stopped and concentrations of metabolites with high turnover rates were maintained at higher concentrations, whereas the metabolism of cells sampled with the microstructure heat exchanger or just centrifugation was stopped less efficiently.

Dietmair et al. (2010) describe considerably lower amounts of extracted metabolites from cells on filters compared to extracts from cell pellets. This was not observed in this study (see also Fig.10).

\section{Conclusions}

Fast filtration is a valuable and reliable tool for metabolome sampling of suspended animal cells. Even metabolites with high turnover rates were detected in higher concentrations compared to other sampling methods. Furthermore, leakage of metabolites from the cells during sampling is low, as is cell damage.

There is no obvious advantage using the microstructure heat exchanger method in comparison to centrifugation at $-2{ }^{\circ} \mathrm{C}$. This is most likely due to the extended period of time in which the cells are handled at about $0{ }^{\circ} \mathrm{C}$, which is not sufficient to completely stop the metabolic activity.

Depending on the nature and the turnover rates of the target metabolites, a simple sampling method like centrifugation might be sufficient to yield some results. But to generate a snapshot of the metabolic state of a cell at any given moment, the fast filtration method presented in this study is a reliable tool superior to other sampling techniques like microstructure heat exchanger or rapid centrifugation.

The cold methanol extraction described in this work is more capable of releasing metabolites from cells on filters than the method used by Dietmair et al. (2010). This may be due to the longer exposure of the cells to the extraction reagent (i.e. $24 \mathrm{~h}$ as opposed to $10 \mathrm{~min}$ ). 
Furthermore, inert borosilicate glass-fiber filter material was used in this study to prevent interactions of metabolites with the filter material. The composite PFTE and PE filters used by Dietmair et al. (2010) might cause adherence of metabolites to the filter material.

Thus, the presented combination of fast filtration and cold methanol extraction can be considered as well applicable for sampling of intracellular metabolites from suspended animal cells.

\section{References}

Ataullakhanov FI and Vitvitsky VM (2002) What determines the intracellular atp concentration. Biosci Rep 22:501-511

Bennett BD, Yuan J, Kimball EH, and Rabinowitz JD (2008) Absolute quantitation of intracellular metabolite concentrations by an isotope ratio-based approach. Nat Protoc 3:1299-311

Bolten CJ and Wittmann C (2008) Appropriate sampling for intracellular amino acid analysis in five phylogenetically different yeasts. Biotechnol Lett 30:1993-2000

Büntemeyer H (2010) Off-Line Analysis in Animal Cell Culture. In: Flickinger MC (ed) Encyclopedia of Industrial Biotechnology. Bioprocess, Bioseparation, and Cell Technology

Canelas AB, ten Pierick A, Ras C, Seifar RM, van Dam JC, van Gulik WM, and Heijnen JJ (2009) Quantitative evaluation of intracellular metabolite extraction techniques for yeast metabolomics. Anal Chem 81:7379-7389

Cordell RL, Hill SJ, Ortori CA, and Barrett DA (2008) Quantitative profiling of nucleotides and related phosphate-containing metabolites in cultured mammalian cells by liquid chromatography tandem electrospray mass spectrometry. J Chrom B 871:115-124 
de Koning W and van Dam K (1992) A method for the determination of changes of glycolytic metabolites in yeast on a subsecond time scale using extraction at neutral ph. Anal Biochem 204:118-123

Dietmair S, Timmins NE, Gray PP, Nielsen LK, and Krömer JO (2010) Towards quantitative metabolomics of mammalian cells: development of a metabolite extraction protocol. Anal Biochem 404:155-164

Faijes M, Mars AE, and Smid EJ (2007) Comparison of quenching and extraction methodologies for metabolome analysis of lactobacillus plantarum. Microb Cell Fact 6:27

Ritter JB, Genzel Y, and Reichl U (2008) Simultaneous extraction of several metabolites of energy metabolism and related substances in mammalian cells: optimization using experimental design. Anal Biochem 373:349-369

Sauter T (2003) Die bakterielle Signalverarbeitung am Beispiel des Sucrose Phosphotransferasesystems in Escherichia coli - Modellierung und experimentelle Überprüfung. Dissertation, University of Stuttgart

Schaub J, Schiesling C, Reuss M, and Dauner M (2006) Integrated sampling procedure for metabolome analysis. Biotechnol Prog 22:1434-1442

Sellick CA, Hansen R, Maqsood AR, Dunn WB, Stephens GM, Goodacre R, and Dickson AJ (2009) Effective quenching processes for physiologically valid metabolite profiling of suspension cultured mammalian cells. Anal Chem 81:174-183

Sharpe RL and Milligan CL (2003) Lactate efflux from sarcolemmal vesicles isolated from rainbow trout oncorhynchus mykiss white muscle is via simple diffusion. J Exp Biol 206:543-549 
Teng Q, Huang W, Collette T, Ekman D, and Tan C (2009) A direct cell quenching method for cell-culture based metabolomics. Metabolomics 5:199-208

Villas-Bôas SG, Højer-Pedersen J, Akesson M, Smedsgaard J, and Nielsen J (2005) Global metabolite analysis of yeast: evaluation of sample preparation methods. Yeast 22:1155-1169

Wellerdiek M, Winterhoff D, Reule W, Brandner JJ, and Oldiges M (2009) Metabolic quenching of corynebacterium glutamicum: efficiency of methods and impact of cold shock. Bioprocess Biosyst Eng 32:581-592

Wiendahl C, Brandner JJ, Küppers C, Luo B, Schygulla U, Noll T, and Oldiges M (2007) A microstructure heat exchanger for quenching the metabolism of mammalian cells. Chem Eng Technol 30:322-328 
Fig. 1 Dependence of $\mathrm{LDH}$ release and vacuum applied to the filtration device. Reference experiments with centrifugation of cells at $3000 \mathrm{rcf}$ for $1 \mathrm{~min}$ exhibited a release of LDH during sampling of $2.56 \% \pm 0.66 \%$ compared to the total $\mathrm{LDH}$ amount in the sample cell solution. For each cell count three individual experiments were done. LDH measurements were done in triplicates 


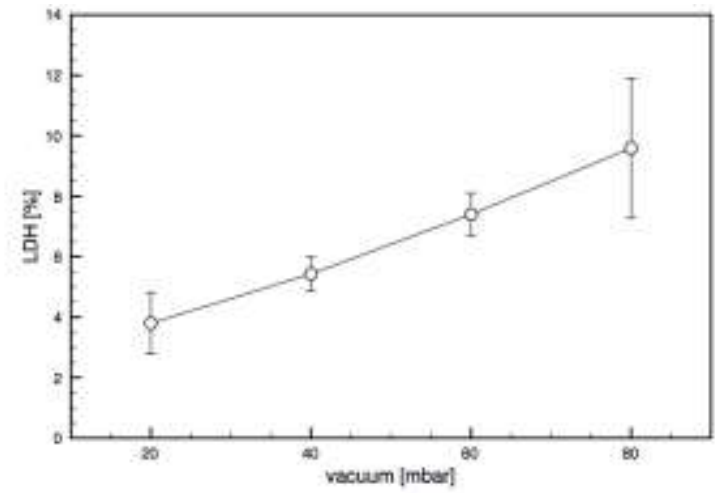


Fig. 2 Correlation of vacuum and filtration time for cell suspension and sodium chloride washing solution. Error bars indicate the standard deviation of four individual experiments 


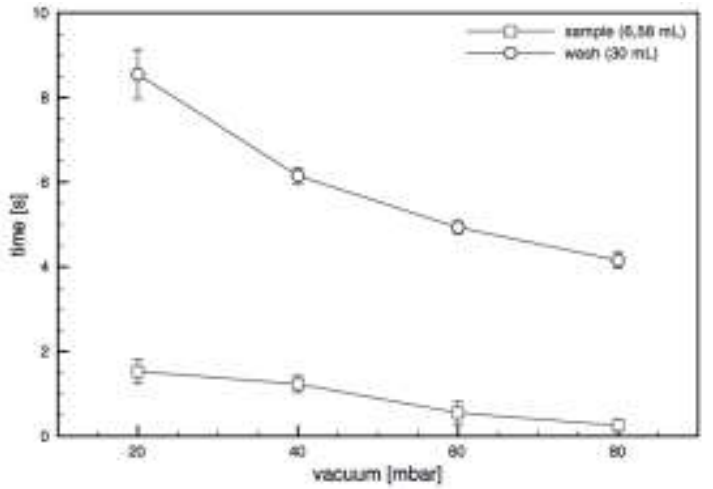


Fig. 3 Correlation of cell number on filter and extracted metabolite content compared to a reference sample taken by centrifugation. Error bars indicate standard deviation of three individual experiments 


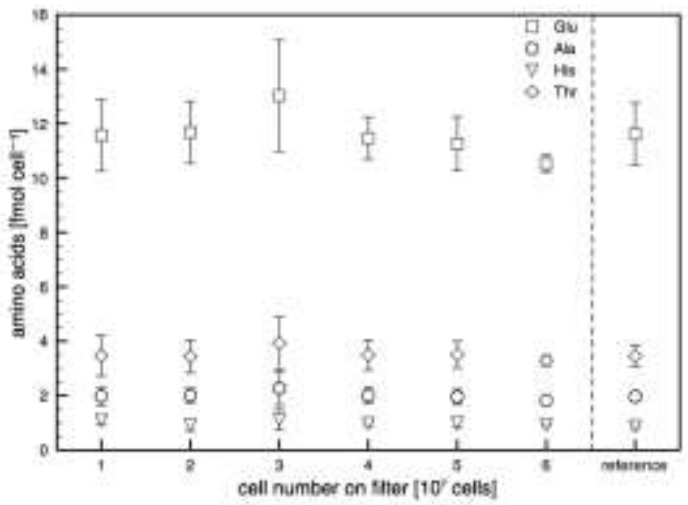


Fig. 4 Leakage of ATP after sampling using fast filtration. Leakage was assessed by comparison of the ATP amount measured in extracts from $5 \times 10^{7}$ cells on filter and measured in the washing solution. Error bars indicate the standard deviation of three individual experiments 


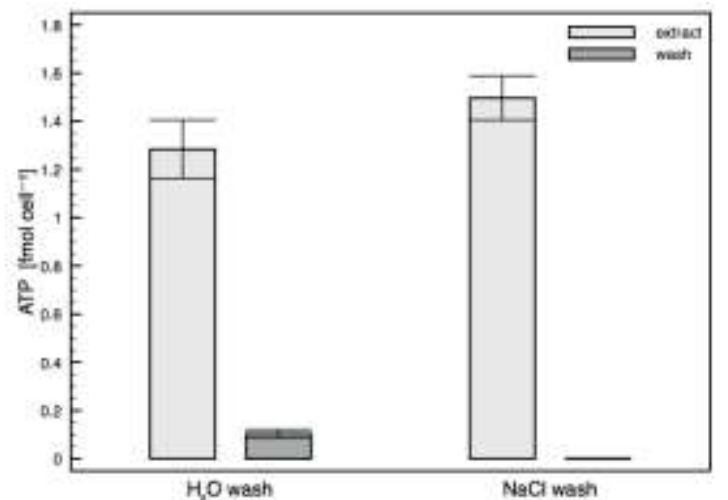


Fig. 5 Leakage of pyruvate after sampling with fast filtration. Leakage was assessed by comparison of the pyruvate amount measured in extracts from $5 \times 10^{7}$ cells on filter and measured in the washing solution. Error bars indicate the standard deviation of three individual experiments 


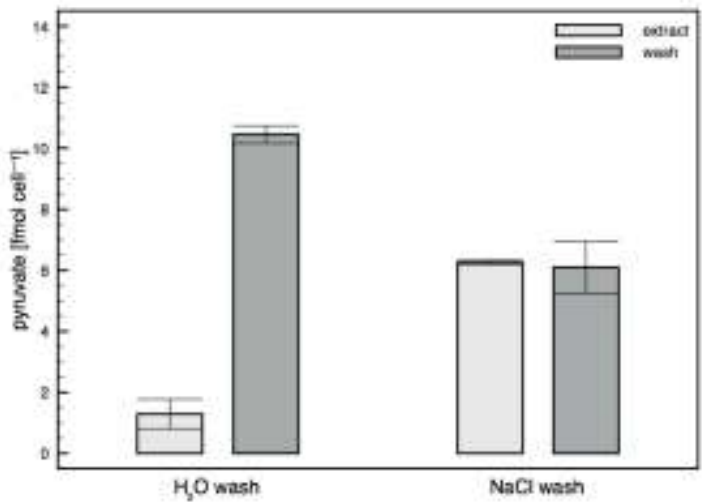


Fig. 6 Cultivation of CHO DP12 cells in a 21 bioreactor. Arrows indicate sampling points for metabolome analysis. Initial cell density was $5 \times 10^{5}$ cells ml $^{-1}$. The temperature was controlled at $37{ }^{\circ} \mathrm{C}$. The stirring speed with two Rushton turbines was $150 \mathrm{rpm}$. PO and pH were controlled at $40 \%$ DOT and $\mathrm{pH} 7.2$, respectively 


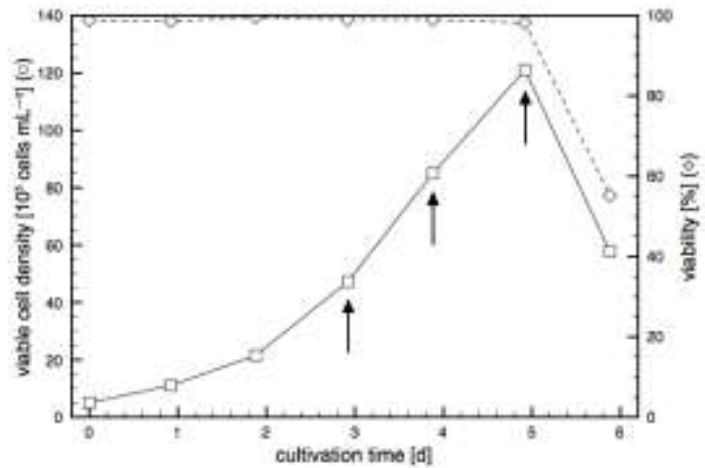


Fig. 7 Adenylate energy charge at different time points in $\mathrm{CHO}$ bioreactor cultivation using different sampling methods. Error bars indicate the standard deviation of four individual measurements 


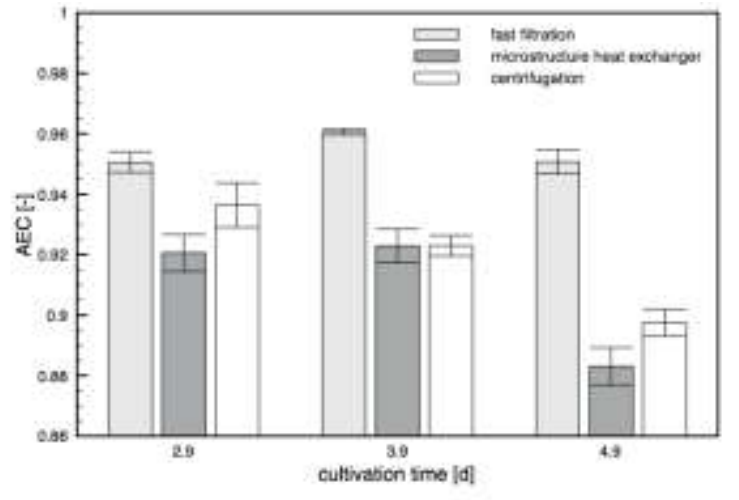


Fig. 8 Intracellular glucose concentration measured by GC-MS for the different sampling methods during the cultivation. The ratio of glucose peak to ribitol peak (internal standard) is given. Error bars indicate the standard deviation of six individual measurements 


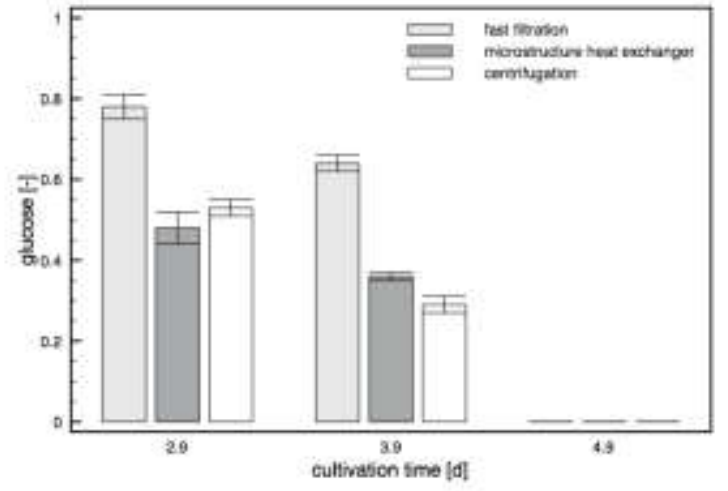


Fig. 9 Ribose/ribulose 5-phosphate concentration in the extracts measured by LC-MS for the different sampling methods during the cultivation. Due to the similar chemical structure a distinction between ribose 5-phosphate and ribulose 5-phosphate was not possible. Error bars indicate the standard deviation of four individual measurements 


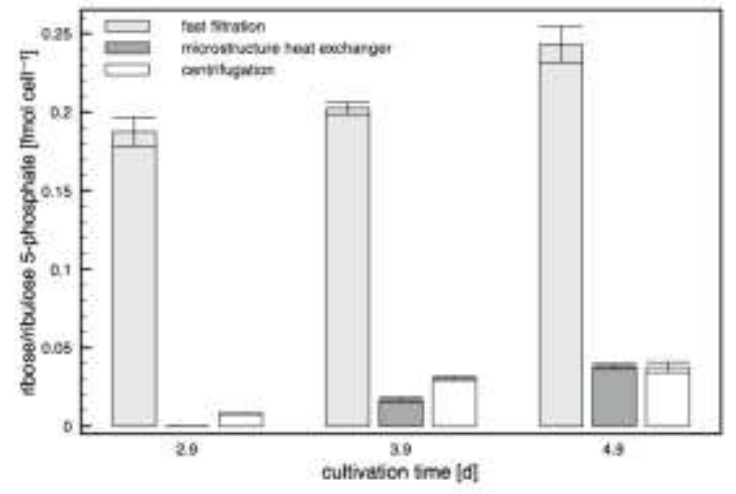


Fig. 10 Metabolite concentrations in the extracts measured by LC-MS for the different sampling methods. Samples are from the first sampling point during the cultivation (day 3). Error bars indicate the standard deviation of four individual measurements 


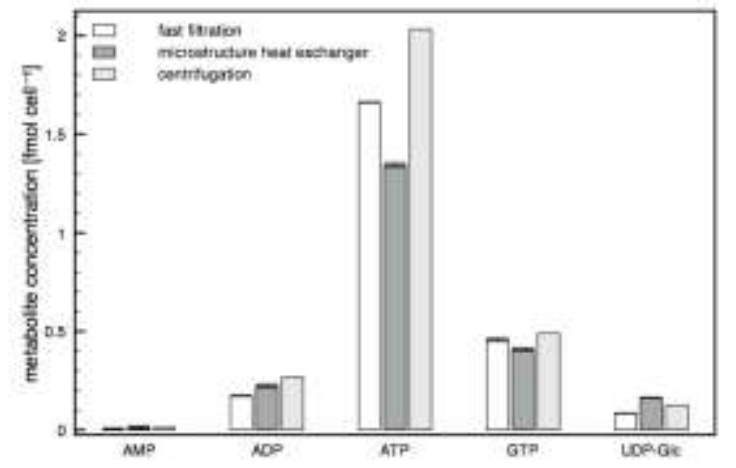




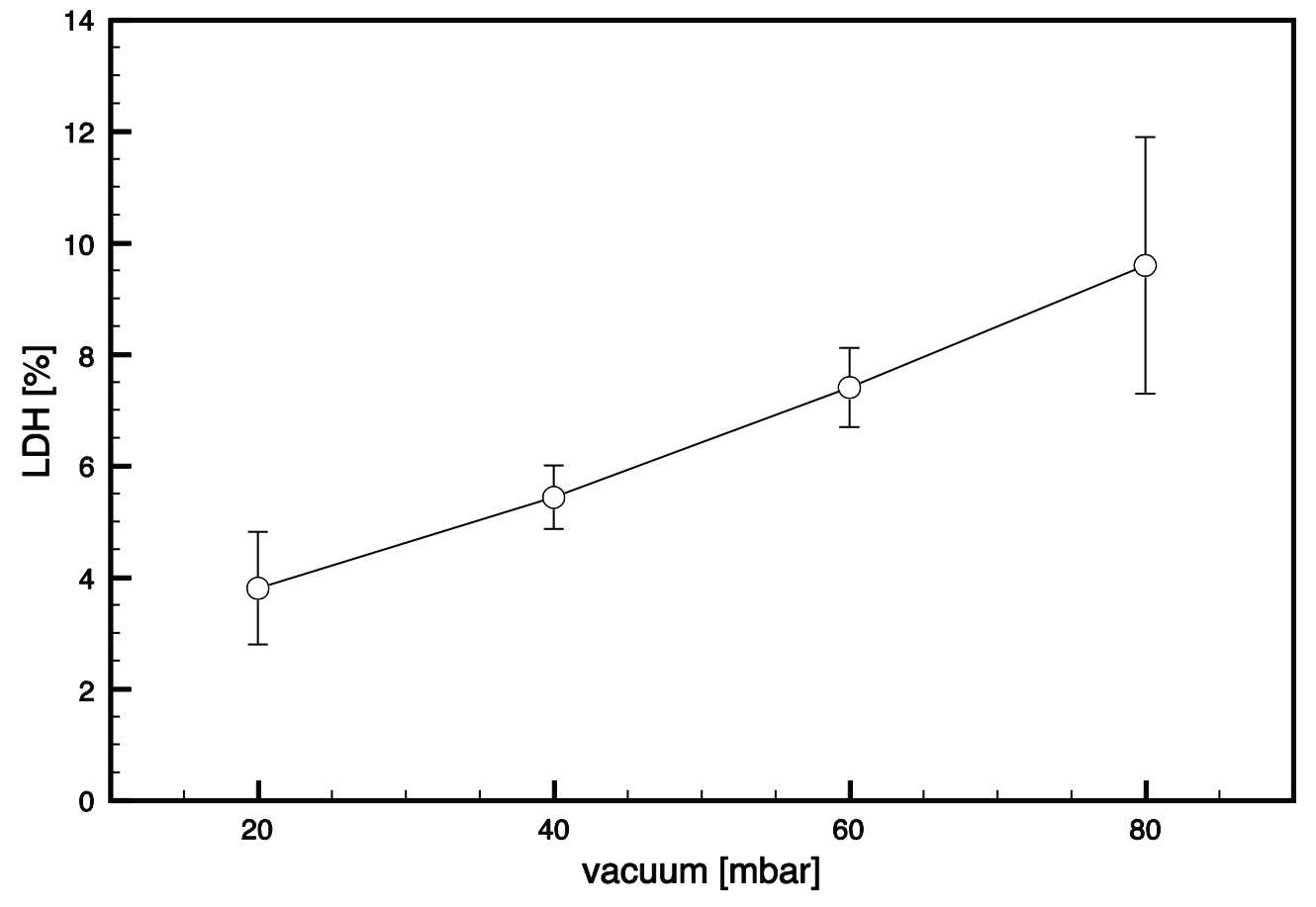




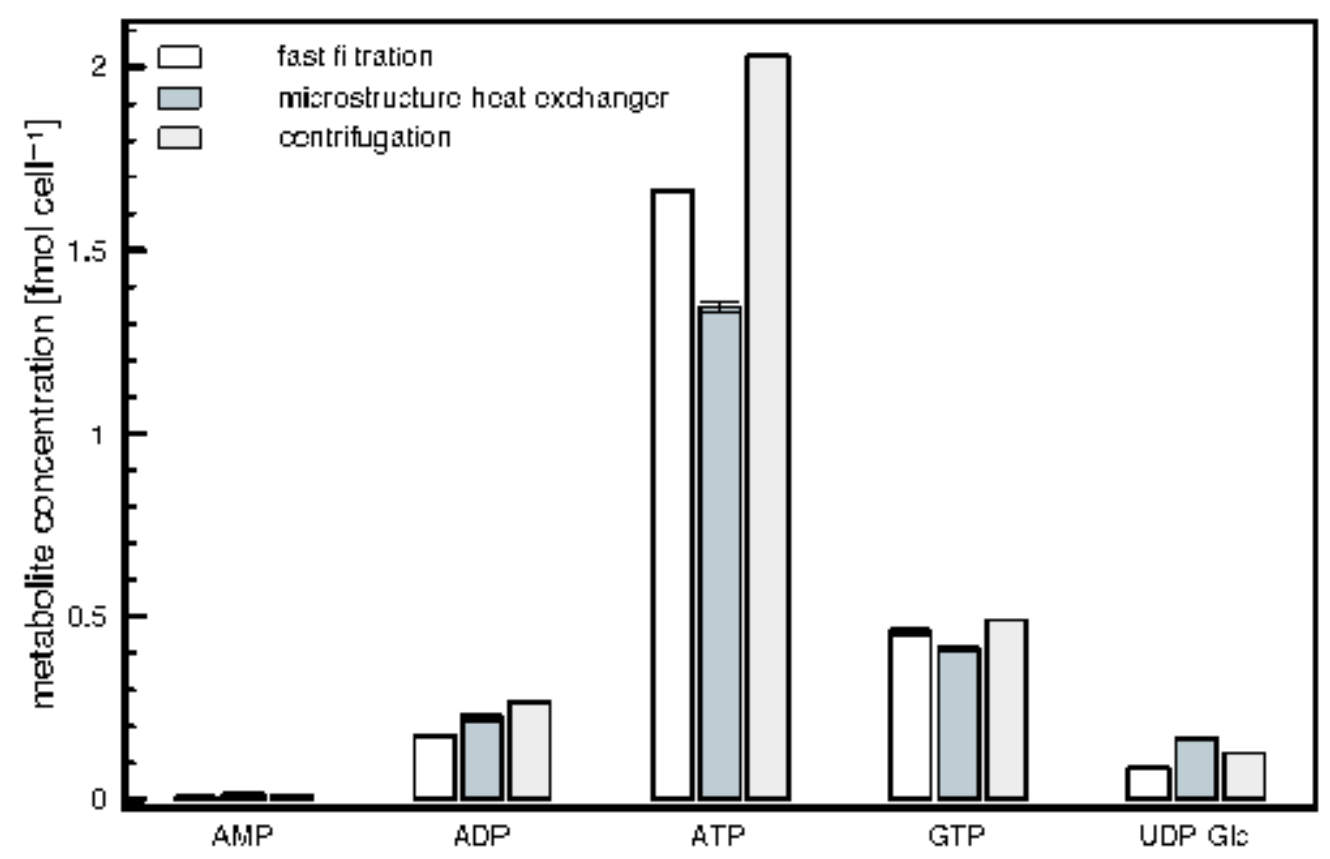




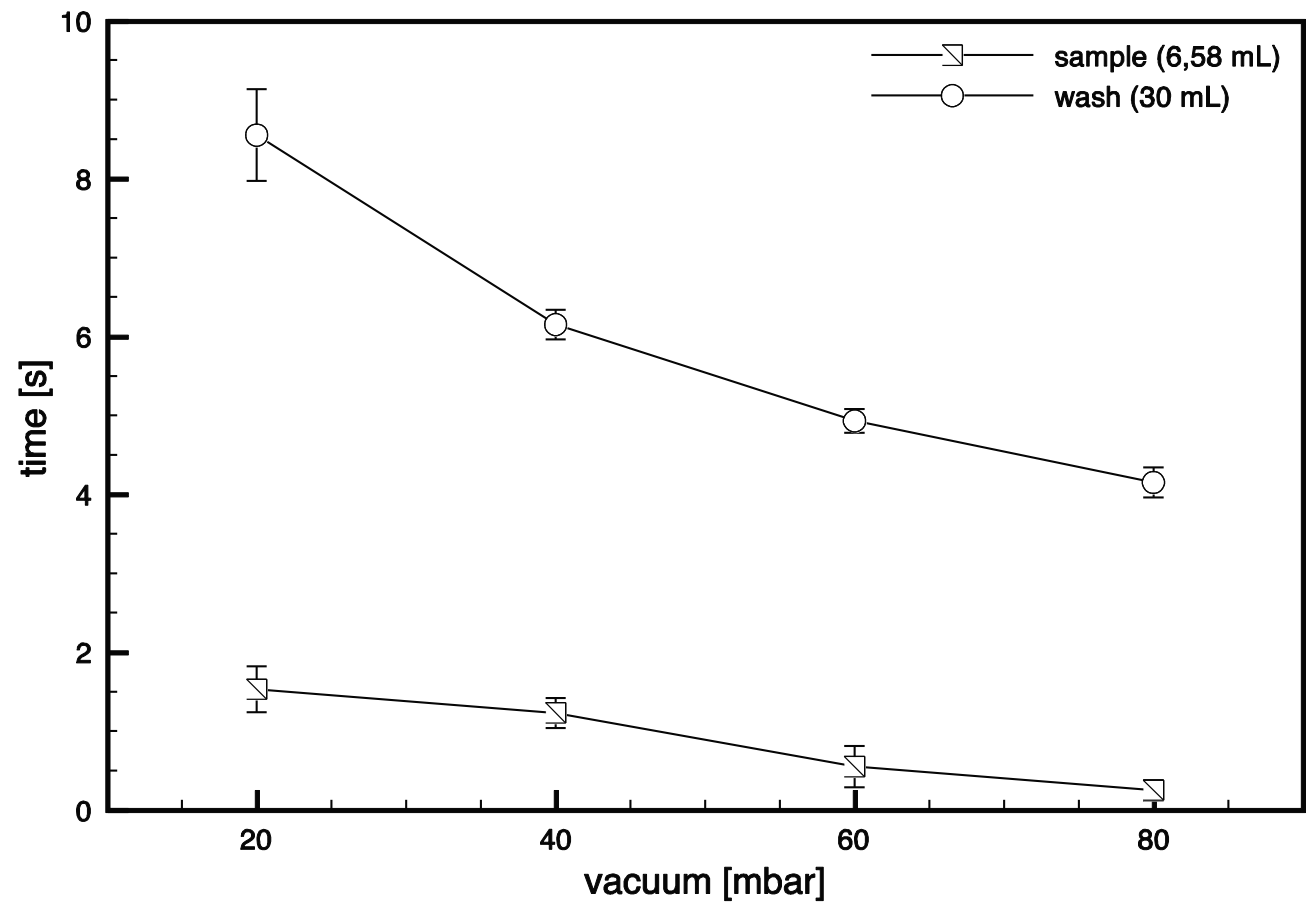




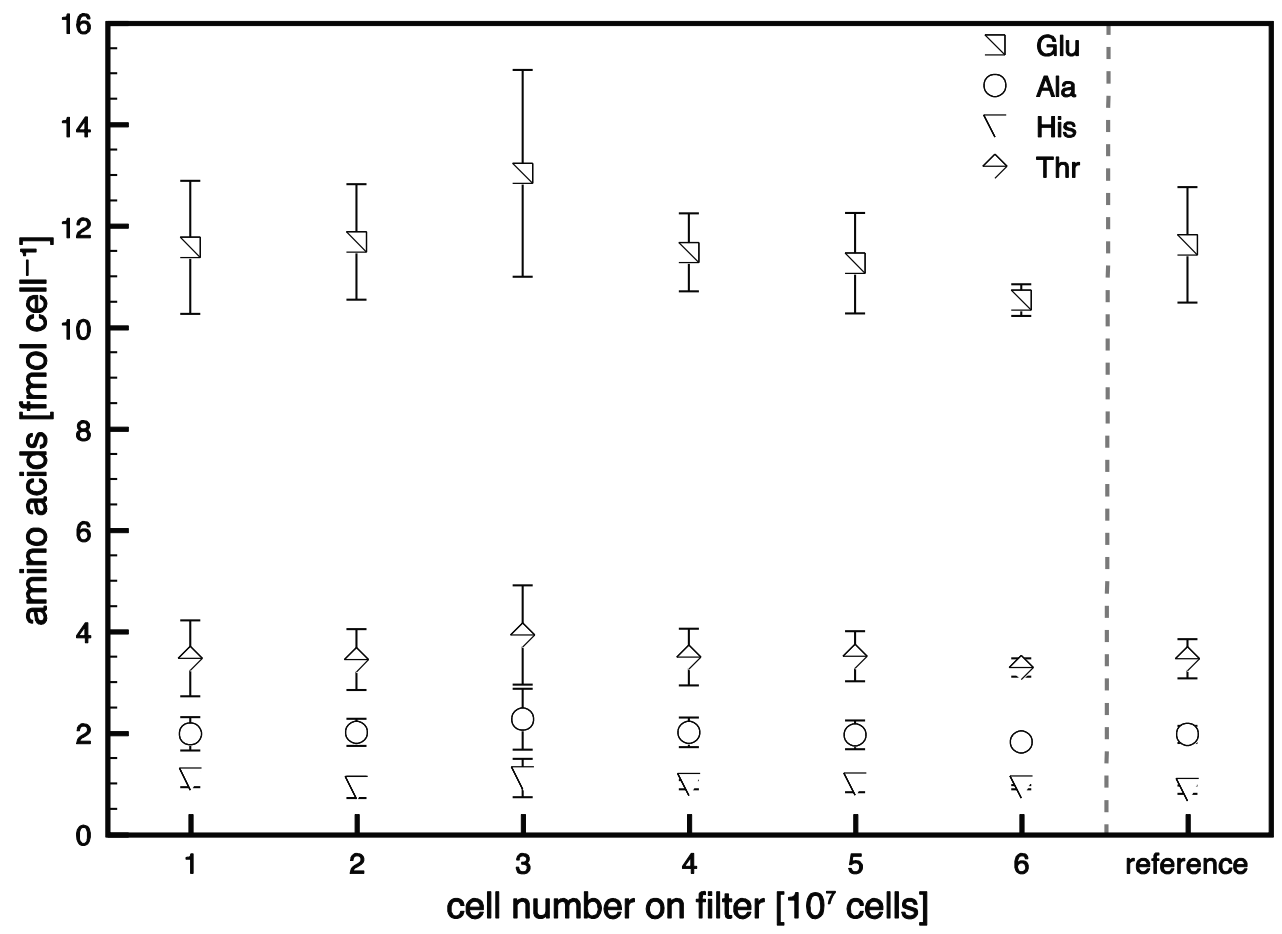




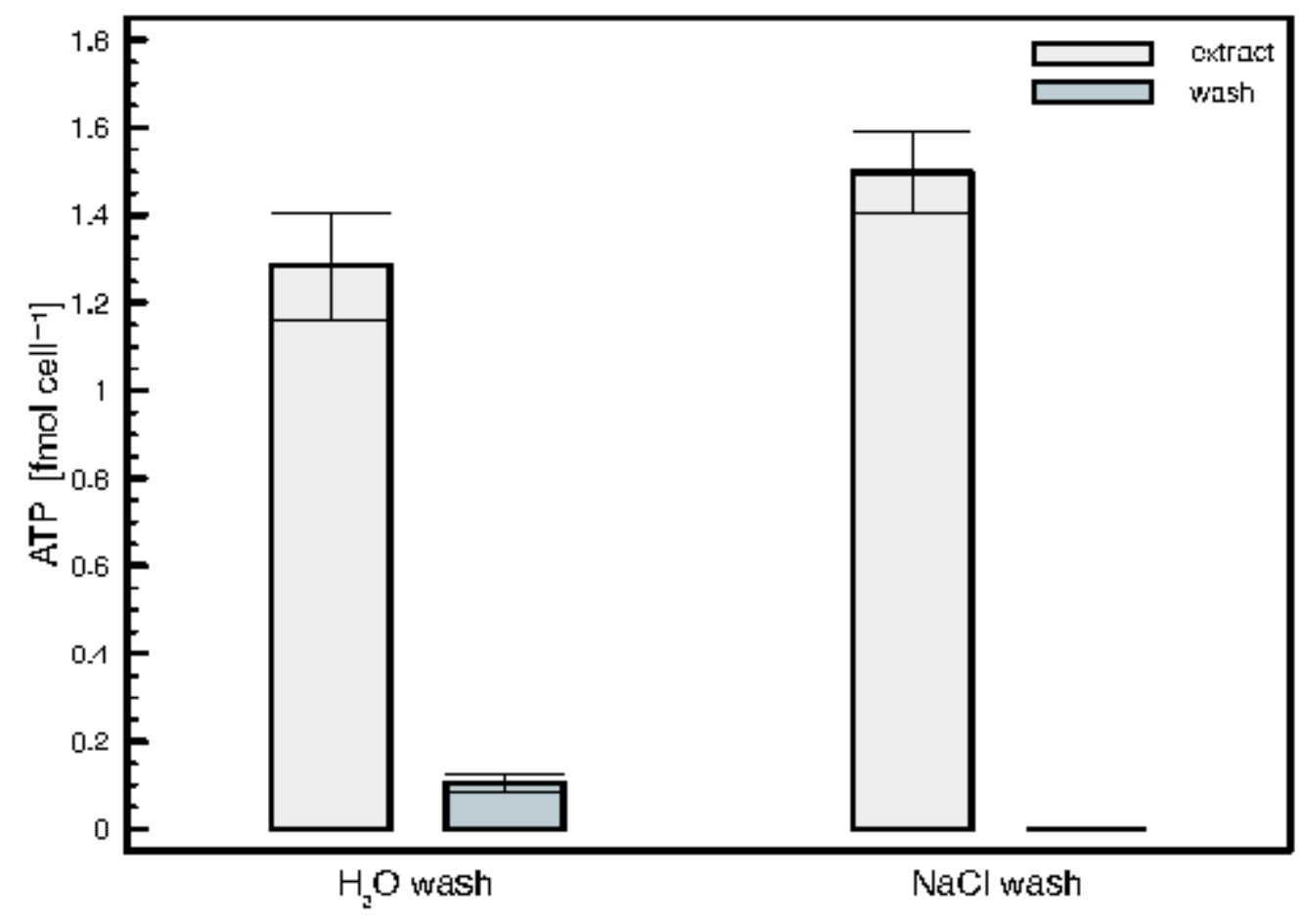




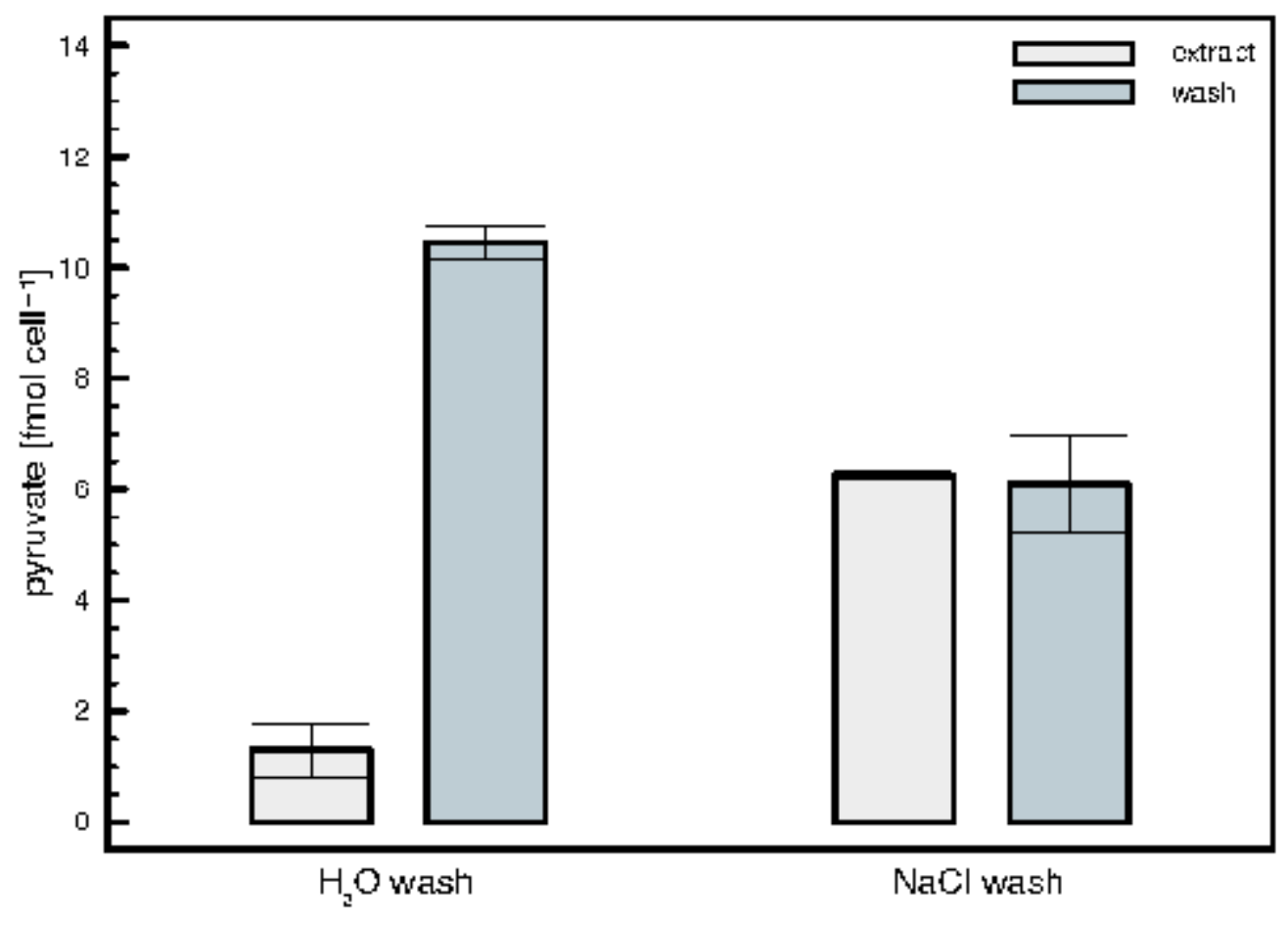




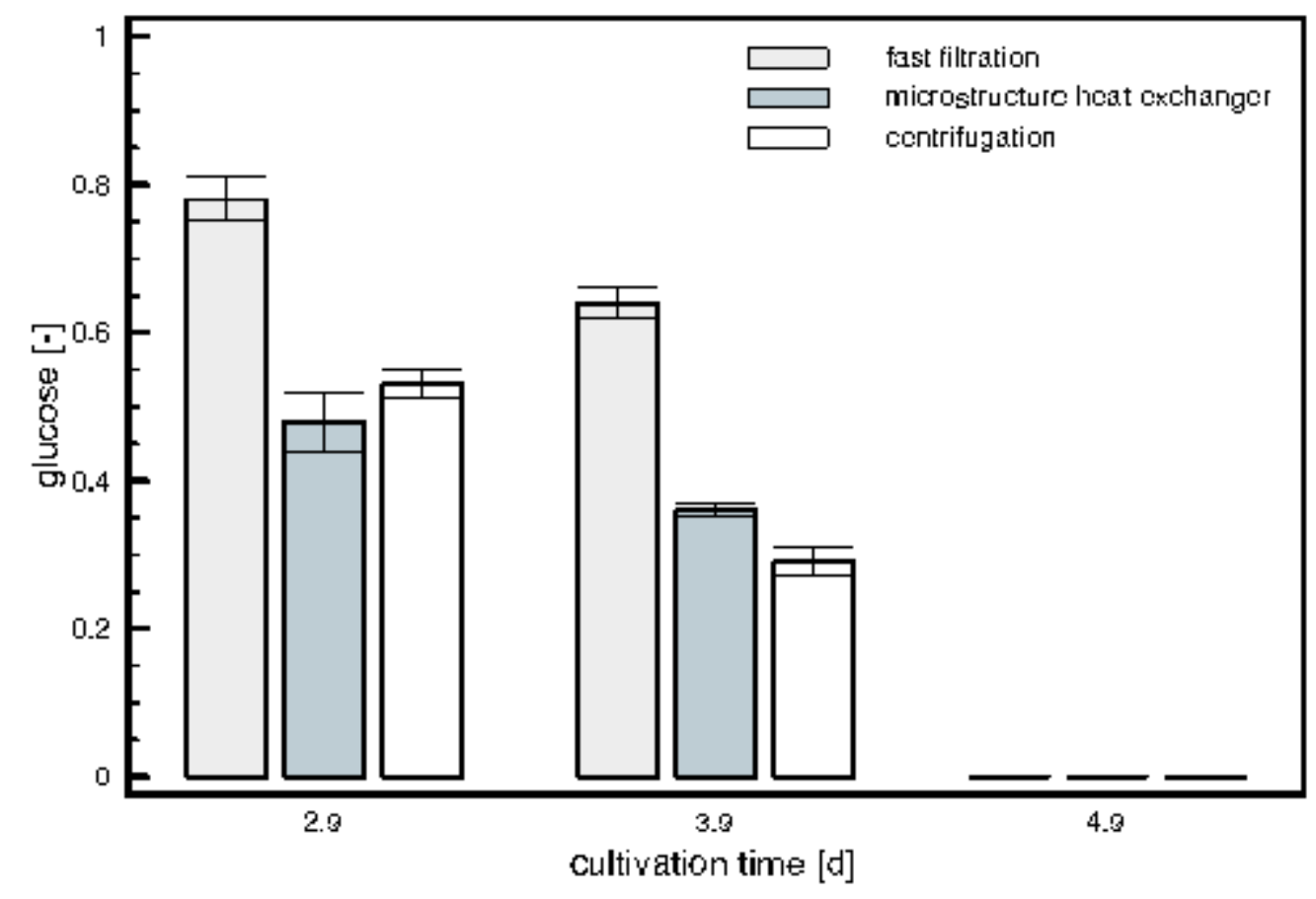




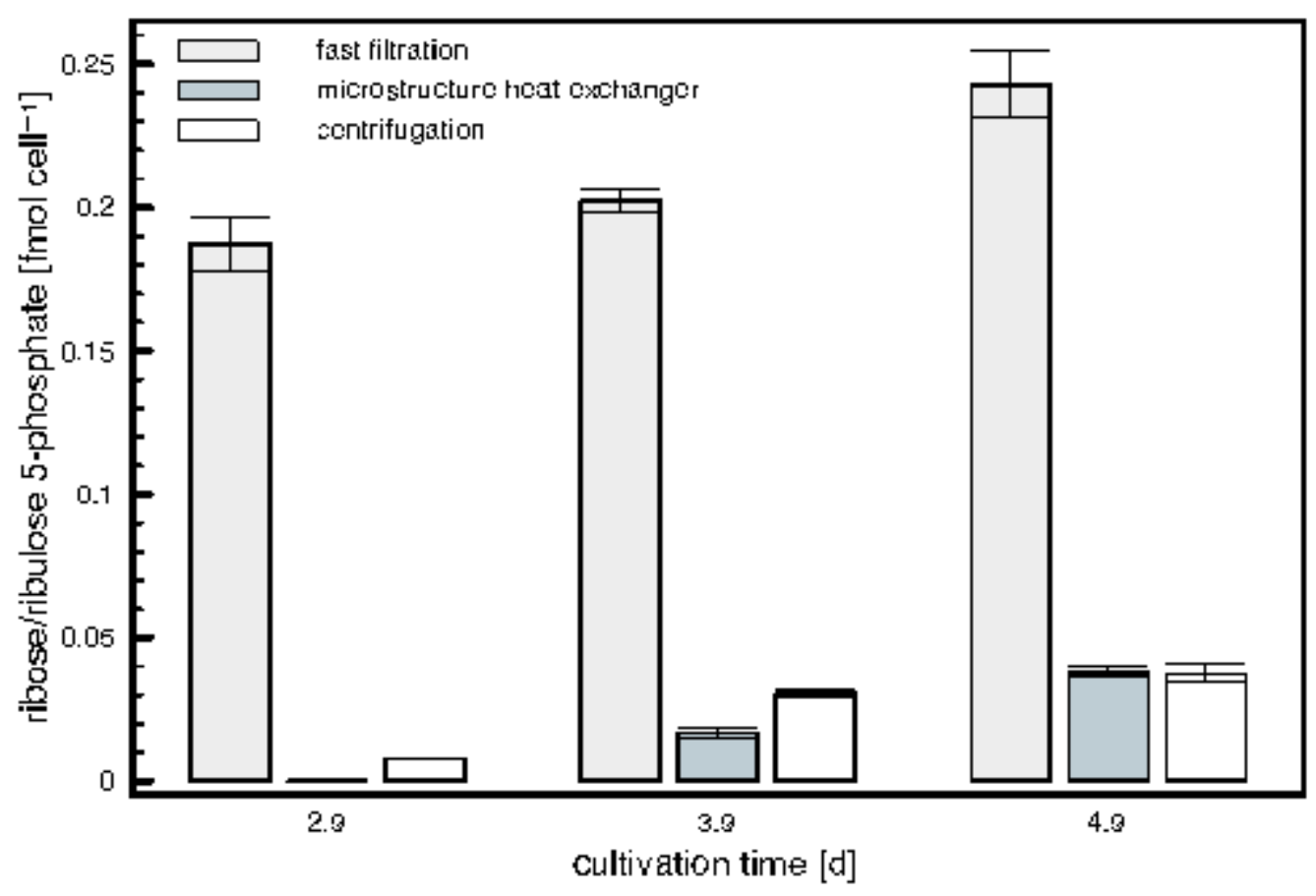

